\title{
STRATEGI KEWIRAUSAHAAN TERHADAP BUSINESS PERFORMANCE DIMEDIASI KEMAMPUAN KREATIVITAS DAN INOVASI PADA USAHA GARMEN DI PASAR TRADISIONAL BANDUNG
}

\author{
Rizki Zulfickar ${ }^{1}$ Amir Machmud ${ }^{2}$, A. Sobandi ${ }^{3}$ \\ ${ }^{1}$ Universitas Pendidikan Indonesia, ${ }^{2}$ Universitas Pendidikan Indonesia, ${ }^{3}$ Universitas Pendidikan \\ Indonesia \\ 1rizkizul@upi.edu,2ªmir@upi.edu, ${ }^{3}$ ade@upi.edu
}

\begin{abstract}
Abstrack
The purpose of this research is to find out the effect of Entrepreneurship Strategy on Business Performance mediated by the ability of Creativity and Innovation in Garment Business in Bandung Traditional Market. Study population, 280 Bandung garment businesses. Determination of sample size uses the Slovin formula with a sample size of 165 Bandung garment businesses.. Data collection techniques using a questionnaire. Data analysis uses descriptive statistical analysis and Multiple Mediation Regression analysis. Descriptive analysis of results obtained that the Business Performance in the good category, Entrepreneurship Strategy in the good enough category, Creativity in the good enough category, and Innovation in the good enough category. The results showed that the Entrepreneurship Strategy directly involved Business Performance with a coefficient of determination of $(57.7 \%)$. Mediation effect through creativity with a coefficient of determination of (19.1\%), mediation effect through innovation with a coefficient of determination of (16.7\%), total mediation effect of Creativity and innovation with a coefficient of determination of (81.5\%). The conclusions of the research related to the Entrepreneurship Strategy simultaneously on Business Performance are mediated by Creativity and Innovation in the Garment Business in Bandung Traditional Market.
\end{abstract}

Keywords: Entrepreneurship Strategy, Creativity Ability, and Innovation, Business Performance

\section{Pendahuluan}

Perkembangan Informasi dan Teknologi Saat ini membuat perusahaan berada di Era Ekonomi Pengetahuan (Hendarman \& Tjakraatmadja, 2012). Menurut Pratt, (2000) bahwa setiap perusahaan di Era Ekonomi Pengetahuan akan menghadapi tantangan yang berbeda dalam mencapai Keunggulan Kompetitif karena lingkungan bisnis yang sedang berjalan globalisasi, intangibilitas, dan antar konektivitas. Autio, Kenney, Mustar, Siegel, \& Wright, (2014) mengusulkan bahwa perusahaan perlu membangun sumber daya pengetahuan berbasis tindakan kewirausahaan untuk mencapai Keunggulan Kompetitif di era ekonomi. Terkait dengan lingkungan bisnis yang tidak pasti dan memiliki persaingan bisnis yang dinamis, dengan demikian, Keunggulan Kompetitif tradisional semakin kurang relevan karena itu mudah ditiru. Sesuai dengan itu, para ahli seperti Grant, (1996) dan Salunke, Weerawardena, \& McColl-Kennedy, (2019) berpendapat bahwa pengetahuan saat ini adalah sumber daya organisasi untuk mencapai Keunggulan Kompetitif yang sulit ditiru oleh pesaing lain. Salah satu pendekatan baru yang berfokus pada meningkatkan daya saing organisasi bisnis saat berurusan dengan dinamika persaingan adalah dengan menggunakan Kewirausahaan Strategis (Webb, Ketchen, \& Ireland, 2010).

Kewirausahaan Strategis mengambil tindakan kewirausahaan dengan perspektif strategis (Garud, Gehman, \& Tharchen, 2018). Kewirausahaan Strategis adalah kewirausahaan di tingkat organisasi yang menggabungkan Kewirausahaan dan Manajemen Strategis yang juga mencerminkan dua hal seperti pencarian peluang kegiatan dan kegiatan

DOI: 10.33603/ejpe.v8i2.3475

This is an open access article under the CC-BY-SA license

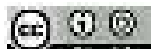


pencarian keuntungan (Withers, Duane, Miller, Harrison, \& Boss, 2016). Oleh karena itu, Bengesi \& Roux, (2014) percaya bahwa dua hal ini biasanya dilakukan oleh perusahaan wirausaha seperti Usaha Kecil Menengah (UKM) untuk membuat kondisi pasar yang tidak seimbang. Kewirausahaan Strategis diakui oleh para peneliti sebagai bidang baru penelitian kewirausahaan yang dilakukan oleh suatu organisasi. Strategis kewirausahaan diposisikan sebagai konsep dimulai pada awal 2000 dan telah berkembang sejak saat itu (Purnomo, Suharyono, Suyadi, \& Utami, 2017). Konsep ini dipengaruhi oleh manajemen strategis dan kewirausahaan dalam organisasi (Hoglund, Caicedo, \& Martensson, 2014). Garud et al., (2018) menekankan bahwa kewirausahaan strategis adalah bentuk manajerial dan kewirausahaan daya tarik bagi para manajer terletak pada kombinasi ekonomi dan behaviorisme di perusahaan, kecepatan yang menjanjikan, fleksibilitas, dan inovasi. Karena itu, akademisi dan praktisi berpendapat bahwa itu strategis kewirausahaan sangat Penting bagi para praktisi dan pembuat kebijakan (Luke, Kearins, \& Verreynne, 2011).

Kemampuan kreativitas menjadi faktor yang mempengaruhi stategi dalam kewirausaha. Kreativitas dianggap sebagai keterampilan yang menggunakan berbagai teknik pembuatan ide (seperti brainstorming), menciptakan ide baru dan berguna, merumuskan, memahami, menganalisa dan mengevaluasi ide asli untuk meningkatkan dan memaksimalkan upaya kreativitas (Ferrari, Cachia, \& Punie, 2009). Salunke et al., (2019) menyatakan bahwa syaratsyarat orang yang kreatif yaitu: (a) keterbukaan terhadap pengalaman, (b) kepercayaan terhadap diri sendiri, (c) menyukai tantangan, (d) tidak sedang tunduk pada pengawasan kelompok, (e) suka berimajinasi, dan mudah untuk beradaptasi. Peran sentral dalam kewirausahaan adanya kemampuan yang kuat untuk menciptakan sesuatu yang baru, misalnya: sebuah organisasi baru, pandangan baru tentang pasar, proses-proses manufacture yang baru, produk-produk dan jasa-jasa baru, cara-cara baru dalam mengelola sesuatu caracara baru dalam pengambilan keputusan (Salunke et al., 2019).

Inovasi adalah elemen penting dalam perusahaan dengan menciptakan aktivitas bisnis baru, dalam menghasilkan pertumbuhan dan memastikan kelangsungan hidup untuk bisnis yang sudah ada untuk mendapatkan keunggulan kompetitif. Namun, intinya adalah bahwa inovasi didorong oleh individu yang kreatif dan giat tidak terjadi secara spontan(Liu \& Bell, 2019). Bisnis fashion membutuhkan kecanggihan teknik manajemen selain kreativitas dan inovasi tingkat tinggi (Mayasari Ginting, ., Rahman, \& Devianto, 2019). Menurut Donaldson \& Donaldson, (2018) Inovasi sangat penting dalam perkembangan produk, karena Inovasi bisa menghasilkan pertumbuhan lebih cepat, meningkatkan segmen pasar, dan menciptakan posisi korporat yang lebih baik. Ada dua dimensi "kreativitas dan inovasi" di industri fashion. Yang pertama menyangkut inovasi produk terkait untuk kreativitas perancang busana / tekstil yang penting untuk menciptakan merek internasional dan pemimpin dunia yang lebih kuat, produk kompetitif. Dimensi kedua menyangkut inovasi pada "bisnis operasi ", penggunaan teknik pemasaran, manajemen rantai pasokan (Fliaster \& Sperber, 2019).

Perhatian terhadap pasar tradisional UKM di Indonesia sebagai bentuk keberpihakan pada masyarakat ekonomi. Umumnya, UKM di pasar tradisional menghadapi dua kendala penting yang harus diperhatikan, yaitu, kendala internal dan eksternal. Yang dimaksud dengan kendala internal adalah kurangnya sumber daya, manajemen, daya tawar, dan legalitas, sementara kendala eksternal berarti tantangan persaingan globalisasi seperti persaingan dengan pasar modern, pusat perbelanjaan modern, harga barang dagangan yang berfluktuasi sejalan dengan fluktuasi dolar Amerika, Kawasan Perdagangan Bebas ASEAN-China, dan Masyarakat Ekonomi ASEAN pada (2016). Kendala-kendala itu menjadi perhatian pemerintah, bisnis agen, dan publik terhadap kelangsungan hidup UKM di pasar tradisional 
dan keberlanjutan pasar tradisional diri. Pemerintah Daerah Jawa Barat khususnya di bidang perdagangan telah membuat program GEMPITA (Gerakan Cinta Pasar Tradisional). Tujuan dari program GEMPITA adalah untuk melindungi Mikro, Kecil dan Usaha Menengah (UKM) di pasar tradisional provinsi Jawa Barat yang mulai berkurang dan terpinggirkan oleh tekanan pasar modern, pusat perbelanjaan modern, serta masyarakat urban gaya hidup. Peraturan daerah ini diwujudkan dengan merevitalisasi 37 pasar tradisional di 25 kabupaten / kota Bandung,Jawa barat Indonesia(Resalawati. A, 2011).

Bandung adalah salah satu kota yang mendapat perhatian untuk revitalisasi pasar tradisional. Berdasarkan data dan informasi dari pemerintah, Pasar Bermatabat sebagai lembaga pemerintah yang mengelola pasar tradisional di Bandung melaporkan bahwa Bandung memiliki 40 pasar tradisional. Namun, keberlanjutannya dari 40 pasar tradisional di Bandung ini dianggap terancam oleh tekanan persaingan pasar modern. Terlebih lagi, ada 3 pasar tradisional yang bisa dikatakan mati atau mati seperti pasar Pagarsih, pasar Lingkar, dan pasar Gatot Subroto sedangkan pasar tradisional lainnya seperti Pasar Kosambi, pasar Kiaracondong, dan pasar Cicadas tampaknya sudah sangat tinggi terancam. Namun berdasarkan pengamatan lapangan, diketahui bahwa dalam persaingan ketat ini, UKM di Indonesia pasar tradisional yang menjadi pusat garmen cenderung memiliki posisi kompetitif yang lebih baik daripada pasar tradisional yang berpusat pada penjualan sayuran, buahbuahan, dan kebutuhan primer lainnya. Juga, selama krisis ekonomi, jumlah pengecer skala mikro dan kecil di pasar tradisional adalah secara mengejutkan meningkat seperti di Pasar Baru, Pasar Andir, dan Pasar Gede Bage. Sebaliknya, pasar tradisional yang menjual sayuran, buah-buahan, dan kebutuhan pokok lainnya cenderung turun, misalnya, Pasar Kosambi, Pasar Cicadas, dan Pasar Mohammad Ramdhan. Fenomena menarik ini menarik untuk dikembangkan lebih jauh diselidiki sehubungan dengan dukungan dari pemerintah Kota Bandung pada keberlanjutan pasar tradisional.

Pasar tradisional garmen di Bandung dikenal sebagai trend setter dan ikon mode garmen untuk orang-orang di sekitar Bandung baik wisatawan domestik maupun mancanegara. Daya saing ini Pusat garmen di Bandung relatif baik di mana ini merupakan pencapaian Keunggulan Kompetitif itu diperoleh secara kolektif dan muncul karena kompetisi yang berkembang. Fakta menunjukkan bahwa UKM secara tradisional pasar tidak hanya bersaing dengan UKM lain tetapi juga ritel garmen di pusat perbelanjaan modern. Mendukung itu, data menjelaskan bahwa ritel garmen di pasar tradisional Bandung bersaing dengan baik dengan sekitar 73 perusahaan skala menengah ritel garmen di mana ia menggunakan konsep factory outlet store serta dengan sekitar 1.200 retail garmen dengan konsep distro (Panduan Wisata Kota Bandung, 2013). Itu persaingan yang sangat kompetitif memotivasi bisnis garmen kecil di pasar tradisional untuk memiliki Keunggulan kompetitif. Meningkatnya persaingan ritel garmen di Bandung merupakan gambaran kenyataan yang disampaikan oleh Salunke et al., (2019) menyatakan bahwa persaingan dalam perusahaan wirausaha memerlukan kemampuan keratif dan inovasi. Artinya, persaingan semacam ini memerlukan perkembangan keinovasian yang akan dihadapi oleh perusahaan wirausaha.

Hipotesis dalam penelitian ini menggambarkan hubungan antara Strategi Kewirausahaan terhadap Business Performance dimediasi Kemampuan Kreativitas dan Inovasi. Langkah kerja yang ditempuh analisis dengan mengunakan Macro PROCESS SPSS version, meliputi : 1) Buka Software SPSS yang sudah terintegrasi dengan Macro PROCESS, 2) buka file data, 3) klik analyze, 4) klik regression, 5) klik PROCESS. Selanjutnya masuk variabel Y ke dalam Outcome variabel, sementara variabel X ke dalam Independent variable, serta variable mediasi ke dalam $M$ variable, selanjutnya pilih nomor 4, klik option: kemudian 
pilih OLS. Effect size, total effect modal. Langkah terakhir pilih continue, klik OK. Diagram statistik untuk model penelitian dapat dijelaskan pada gambar 1 berikut ini:

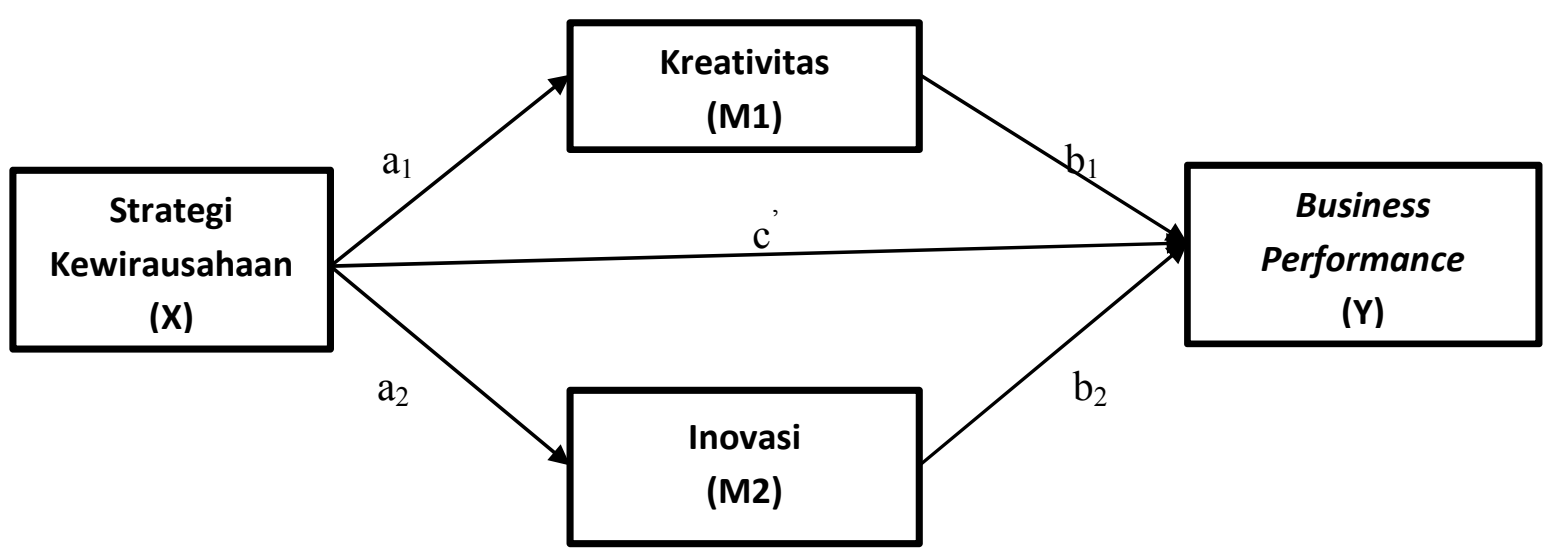

Gambar 1 Paragdima Berpikir

Berdasarkan kerangka pemikiran dan model penelitian diatas, dirumuskan hipotesis sebagai berikut :

$\mathrm{H}_{1} \quad$ : Strategi Kewirausahaan berpengaruh positif dan signifikan terhadap Business Performance

$\mathrm{H}_{2}$ : Kemampuan Kreativitas Memediasi Pengaruh Strategi Kewirausahaan terhadap Business Performance

$\mathrm{H}_{3} \quad$ : Kemampuan Inovasi Memediasi Pengaruh Strategi Kewirausahaan terhadap Business Performance

\section{Metode Penelitian}

Metode yang digunakan dalam penelitian ini adalah metode deskriptif verifikatif dengan teknik pengumpulan data melalui penyebaran angket. Populasi dalam penelitian ini adalah para pemilik Usaha kecil dan menengah garmen di Bandung yang berjumlah sebanyak 280 . Dalam penentuan jumlah sampel menggunakan teknik penarikan sampel menggunakan rumus Slovin taraf kesalahan 5\% sehingga diperoleh sampel sebanyak 165 responden. Analisis menggunakan regresi multiple mediasi persamaan regresi tersebut kemudian diestimasi. Analisis regresi digunakan untuk mengetahui pengaruh langsung Strategi kewirausahaan terhadap Business Performance, efek mediasi Kreativitas dan Inovasi pada Strategi kewirausahaan terhadap Business Performance, dan pengaruh total seluruh variabel.

\section{Hasil Dan Pembahasan}

Gambaran Karakteristik Responden. Berdasarkan hasil kuesioner yang disebarkan kepada 34 responden yaitu para pemilik usaha kecil dan menengah garmen Bandung.

Tabel 1 Karakteristik Responden Pemilik Usaha Garmen Bandung

\begin{tabular}{ccccc}
\hline No & Karakteristik & \multicolumn{1}{c}{ Diskripsi } & \multicolumn{2}{c}{ Distribusi } \\
\hline $\mathbf{1}$ & Lokasi & Pasar Baru & 59 & 35,76 \\
\hline & Pasar Andir & 45 & 27,27 \\
\hline & Pasar Ujung Berung & 32 & 19,39 \\
\hline & & C) 2020 Edunomic: Jurnal Ilmiah Pendidikan Ekonomi \\
& & Fakultas Keguruan dan Ilmu Pendidikan
\end{tabular}




\begin{tabular}{cclcc}
\hline & & Pasar Gede Bage & 30 & 18,18 \\
\hline & & Total & $\mathbf{8 4}$ & $\mathbf{1 0 0 \%}$ \\
\hline $\mathbf{2}$ & Status & Bisnis Keluarga & 46 & 27,88 \\
\hline & & Bisnis Sendiri & 119 & 72.12 \\
\hline & Total & $\mathbf{8 4}$ & $\mathbf{1 0 0 \%}$ \\
\hline $\mathbf{3}$ & Lama Usaha & 6-9 Tahun & 27 & 16,36 \\
\hline & 10-13 Tahun & 45 & 27,27 \\
\hline & 14-20 Tahun & 93 & 56,36 \\
\hline & Total & $\mathbf{3 4}$ & $\mathbf{1 0 0 \%}$ \\
\hline
\end{tabular}

Dari tabel 1 menunjukkan bahwa berdasarkan usaha garmen Bandung terbanyak pada Pasar Baru sebesar 56 atau 35,76\% responden, dan memiliki usaha sendiri sebesar 119 atau $72,12 \%$ responden. Pada lamanya usaha dominan adalah berusia 14-20 tahun yaitu sebanyak 93 atau 56,36\% responden. Kenyataan tersebut dapat membuktikan bahwa sebagian besar para pemilik usaha kecil dan menengah garmen Bandung memiliki pengalaman usaha, sehingga dimana usaha yang dilakukan oleh pemilik pengalaman yang cukup dalam menjalankan usaha yang dilakukan. Hasil pengujian hipotesis mengunakan regresi SPSS 25 dibantu dengan program Process untuk menghitung nilai regresi pada variable secara simultan dan diperoleh nilai koefisien masing-masing variable pada model. Hasil pengolahan regresi menunjukkan bahwa untuk setiap hubungan memiliki p-value $<0,05$ yang berarti regresi seluruh variable bersifat signifikan. Hal ini menunjukkan bahwa H0 ditolak, dengan kata lain terdapat pengaruh yang signifikan antara variable eksogen terhadap variable endogennya. Bentuk kerangka model hasil penelitian sesuai dengan teori multiple mediator dimana terdapat ringkasan pengaruh langsung, tidak langsung, dan pengaruh total seluruh variable dapat dilihat pada gambar 2 berikut ini:
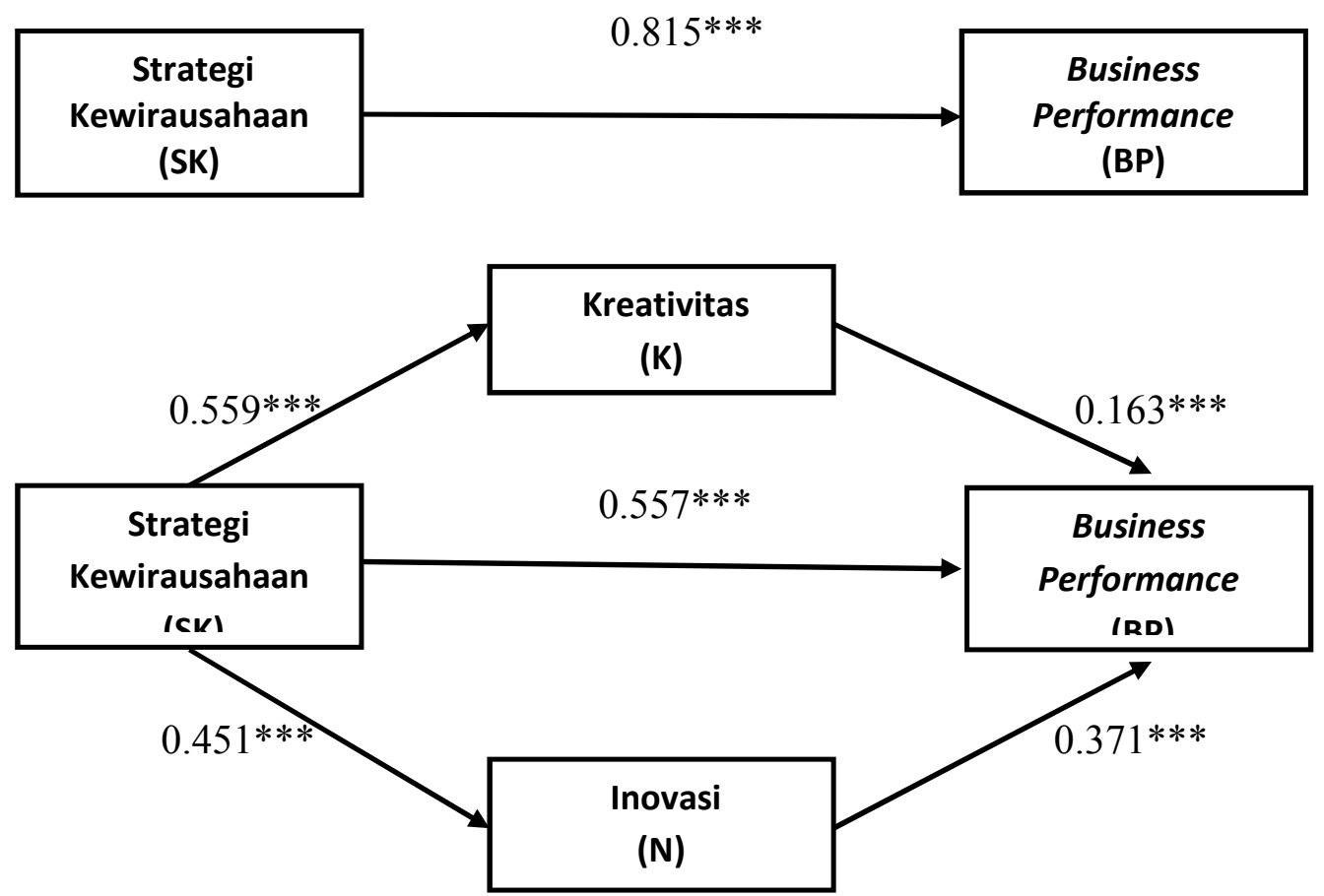

Gambar 2 Hasil Regresi Model Penelitian

p-ISSN 2337-571X $\mid e-I S S N \underline{\text { 2541-562X }}$

(C) 2020 Edunomic: Jurnal Ilmiah Pendidikan Ekonomi Fakultas Keguruan dan Ilmu Pendidikan 
Dari gambar tersebut dapat diketahui persamaan metematis pengaruh total SK terhadap BP pada gambar 2 sebagai berikut:

$\mathrm{BP}=26.467+0.815 \mathrm{SK}+$ eo

Persamaan (1) mendeskripsikan besarnya pengaruh koefisien total variable SK terhadap BP (jalur c,) sebesar 0.815 yang artinya setiap kenaikan 1 nilai SK mengakibatkan kenaikan BP sebesar 0.815. pengaruh total merupakan penjumlahan dari pengaruh langsung (direct effect) ditambah pengaruh tidak langsung (indirect effect), atau c $=c^{\prime}+a b$.

Selanjutnya, dapat diketahui besarnya pengaruh tidak langsung variable SK terhadap variable BP melalui $\mathrm{K}$ (jalur a1 x b1), mealalui variable I (jalur a2 x b2), dan pengaruh tidak langsung SK terhadap BP melalui $\mathrm{K}$ dan I, sehingga diperoleh persamaan matematis sebagai berikut:

$$
\begin{array}{ll}
\mathrm{K} & =3.088+0.559 \mathrm{SK}+\mathrm{e} 1 \\
\mathrm{I} & =0.756+0.451 \mathrm{SK}+\mathrm{e} 2 \\
\mathrm{BP} & =25.682+0.557 \mathrm{SK}+0.163 \mathrm{~K}+0.371 \mathrm{I}+\mathrm{e} 1
\end{array}
$$

Persamaan (2) mendeskripsikan bahwa setiap kenaikan 1 nilai SK mengakibatkan kenaikan nilai K sebesar 0.559. Selanjutnya dari persamaan (3) dapat diketahui bahwa setiap kenaikan 1 nilai SK mengakibatkan kenaikan nilai I sebesar 0.451 Sedangkan, pada persamaan (4) dapat dideskripsikan bahwa BP dipengaruhi oleh ketiga variable yang berbeda, yaitu SK, K, dan I yang masing-masing memiliki koefisien efek yang signifikan.

\begin{tabular}{|c|c|c|c|c|c|c|c|c|c|}
\hline \multicolumn{10}{|c|}{ Variabel } \\
\hline \multirow[t]{2}{*}{ Variabel } & \multicolumn{3}{|c|}{$\mathrm{K}$} & \multicolumn{3}{|c|}{ I } & \multicolumn{3}{|c|}{ BP } \\
\hline & Koef & $T(f)$ & $\mathrm{P}$ & Koef & $T(f)$ & $\mathrm{P}$ & Koef & $T(f)$ & $\mathrm{P}$ \\
\hline SK & $\mathrm{a}^{1} 0.559$ & 0.403 & 0.000 & 0.451 & 0.312 & 0.000 & $\mathrm{c} 0.557$ & 0.109 & $<.001$ \\
\hline K & - & - & - & - & - & - & $b_{1} 0.163$ & 0.154 & 0.291 \\
\hline I & - & - & - & - & - & - & $\mathrm{b}_{2} 0.371$ & 0.199 & 0.064 \\
\hline Constant & ${ }^{\mathrm{i}} \mathrm{m}_{1} 3.087$ & 2.154 & 0.154 & 0.756 & 1.668 & 0.651 & $\mathrm{i}_{\mathrm{y}} 25.682$ & 3.704 & $<.001$ \\
\hline \multirow[t]{2}{*}{$\mathbf{R}^{2}$} & & \multicolumn{2}{|c|}{$\mathrm{R}^{2} 0.542$} & \multicolumn{3}{|c|}{$\mathrm{R}^{2} 0.561$} & \multicolumn{3}{|c|}{$\mathrm{R}^{2} 0.488$} \\
\hline & \multicolumn{3}{|c|}{$\mathrm{F}(1.163)=9.170, \mathrm{p}<.001$} & \multicolumn{3}{|c|}{$\mathrm{F}(1.163)=5.500, \mathrm{p}<.001$} & \multicolumn{3}{|c|}{$\mathrm{F}(3.161)=25.978, \mathrm{p}<.001$} \\
\hline
\end{tabular}

Tabel 2

Ringkasan Hasil Uji Hipotesis Model Variabel Mediasi Paralel

Sumber: Analisis data SPSS 25

Berdasarkan Tabel 2 diperoleh angka $\mathrm{R}^{2}$ sebesar 0.542 , artinya variable $\mathrm{K}$ pada model mampu menjelaskan variansi variable BP sebesar 54,2\%. Selanjutnya, pada variable I diperoleh $\mathrm{R}^{2}$ sebesar 0.561 , yang berarti variable I pada model mampu menjelaskan variable BP sebesar 56,1\%. Mediasi variable $\mathrm{K}$ dan I dapat menjelaskan variable SK terhadap variansi variable BP sebesar 0.488 atau 48,8\%. Lebih lanjut, ringkasan pengaruh mediasi Internal Kreativitas, Inovasi dan ringkasan pengaruh total dan pengaruh langsung variable Strategi kewirausahaan terhadap Business Performance tersaji pada Tabel 3 berikut ini: 
Tabel 3

Total Efek, Efek Langsung, dan Efek Tidak Langsung

\begin{tabular}{|c|c|c|c|c|c|c|}
\hline & Efek & SE & $\mathbf{T}$ & $\mathbf{P}$ & BootLLCI & BootULCI \\
\hline Total Efek & 0.815 & 0.069 & 11.760 & 0.000 & 0.679 & 0.952 \\
\hline Efek Langsung & 0.557 & 0.109 & 5.630 & 0.000 & 0.339 & 0.774 \\
\hline $\begin{array}{l}\text { Total efek tidak } \\
\text { langsung }\end{array}$ & 0.259 & 0.087 & & & 0.089 & 0.428 \\
\hline $\mathbf{S K} \rightarrow \mathbf{N S} \rightarrow \mathbf{I B}\left(a_{1} \mathbf{b}_{1}\right)$ & 0.191 & 0.099 & & & 0.086 & 0.304 \\
\hline $\mathrm{SK} \rightarrow \mathrm{PKP} \rightarrow \mathrm{IB}\left(\mathbf{a}_{2} \mathbf{b}_{2}\right)$ & 0.167 & 0.103 & & & 0.053 & 0.360 \\
\hline
\end{tabular}

Sumber: Analisis data SPSS 25

Tabel 3 menunjukkan besarnya nilai koefisien determinasi masing-masing model variable. Nilai koefisien determinasi SK terhadap BP secara langsung adalah sebesar 0.557 yang artinya variable SK pada model mampu menjelaskan variable BP sebesar $55.7 \%$. Selanjutnya, nilai koefisien determinasi SK terhadap BP yang dimediasi oleh K sebesar 0.191 yang mengindikasikan bahwa dengan adanya mediasi variable $\mathrm{K}$, variable SK pada model mampu menjelaskan variable BP sebesar 19.1\%. Terlihat juga nilai koefisien determinasi SK terhadap BP yang dimediasi oleh I adalah sebesar 0.167 yang artinya dengan adanya mediasi variable I, variable SK pada model mampu menjelaskan variansi variable BP sebesar $16.7 \%$. Secara keseluruhan dengan adanya mediasi K dan I terhadap variable SK pada model $\left(\mathrm{c}=\mathrm{c}^{\prime}\right.$ $+a_{1} b_{1}+a_{2} b_{2}$ ) mampu menjelaskan variable BP sebesar 0.815 atau seebsar $81.5 \%$. Hal ini menujukan bahwa secara statistik variabel $\mathrm{K}$ dan I mediasi variabel SK terhadap BP.

Hasil tersebut dapat membuktikan bahwa kedua variabel tersebut memberikan dampak yang secara nyata atas keberhasilan para pemilik usaha kecil dan menengah germen Bandung dalam melakukan strategi atas produk yang dihasilkan. Terkait dengan kemampuan kreativitas para pemilik usaha maka dapat diketahui usaha para pemilik dalam melakukan proses produksi selalu berusaha untuk membuat produk yang bervariasi dalam ukurannya, membuat produk dengan desain yang berbeda dan benar-benar mampu bersaing dengan produk sejenis, menciptakan produk yang memiliki motif yang berbeda dengan motif produk pesaing memeberikan dukungan untuk memaksimalkan kegiatan pemasaran produk yang dihasilkan. Pada sisi yang lain kegiatan promosi yang dilakukan dengan menggunakan cara-cara baru yang lebih komunikatif, berusaha menciptakan produk yang menarik dan berusaha mencari peluang usaha yang baru memberikan jaminan bahwa kegiatan dalam memasarkan produk dapat berjalan sesuai dengan yang direncanakan.

Hasil analisis juga dapat diketahui bahwa inovasi mediasi pada Strategi kewirausahaan terhadap Business Performance usaha kecil dan menengah garmen bandung. Kenyataan tersebut dapat membuktikan bahwa selama ini para pemilik menghasilkan produk berusaha mengikuti teknologi baru yang lebih efisien dengan harapan produk yang dihasilkan benarbenar mampu memberikan jaminan atas kepuasan konsumen. Mengenai kegiatan desain dan pengepakan barang menggunakan teknologi yang lebih efisien memberikan dukungan atas upaya konsumen untuk mendapatkan produk yang benar-benar terjamin. Selain itu selama ini para pemilik juga melakukan promosi mengikuti teknologi informasi yang baru dengan harapan produk dapat dikenal secara luas oleh pasar. Terkait dengan kegiatan inovasi juga dapat dibuktikan dengan kegiatan penjualan barang mengikuti teknologi perbankan yang ada, mensuplay bahan baku dan bahan penunjang dengan menggunakan inovasi yang baru dan saluran distribusi yang digunakan berusaha mencari peluang-peluang yang baru. Beberapa p-ISSN 2337-571X | e-ISSN $\underline{\text { 2541-562X }}$

(C) 2020 Edunomic: Jurnal Ilmiah Pendidikan Ekonomi Fakultas Keguruan dan Ilmu Pendidikan 
aktivitas para pemilik tersebut yang berkaitan dengan inovasi memiliki pengaruh terhadap Strategi kewirausahaan pada usaha kecil dan menengah germen Bandung.

Hasil penelitian ini didukung oleh teori yang dikemukakan oleh Georgellis, Joyce, \& Woods, (2000) mengatakan bahwa bisnis entrepreneurial yang digambarkan lewat kapasitasnya membuat rencana ke depan, kapasitasnya dalam berinovasi dan kemauan mengambil resiko, akan memudahkannya berinovasi, dan juga berkembang dan tumbuh dengan sukses. Hasil penelitian ini juga didukung oleh teori yang dikemukakan oleh Markowska, Grichnik, Brinckmann, \& Kapsa, (2019) yang menyatakan bahwa kewirausahaan (entrepreneur) cenderung berorentasi pada inovasi (innovation) yang didasarkan pada ide baru dan keadaan pasar yang tidak berorentasi pada konsumen, atau yang dikendalikan oleh perkiraan keinginan dan kebutahan pasar (entrepreneur) menargetkan pasarnya melalui seleksi dengan pendekatan dari bawah ke atas (bottom-up) dan rekomendasi dari konsumen dan pengaruh kelompok lainnya dari atas ke bawah (top-down) yang menargetkan dan memposisikan prosesnya.

\section{Simpulan}

Berdasarkan hasil analisis dengan menggunakan mediasi persamaan regresi, maka pada akhirnya dapat ditarik kesimpulan sebagai berikut:

1) Secara langsung Strategi Kewirausahaan berpengaruh secara positif dan signifikan terhadap Business Performance. Artinya perusahaan memerlukan inovasi dan pengenbangan produk baru untuk menjadi lebih efisien dan produktif, serta menawarkan apa yang diharapkan dari mereka karena kecepatan dalam sifat industri fashion. Ini telah menyebabkan inovasi menjadi salah satu bidang paling signifikan dalam perekonomian saat ini.

2) Kreativitas Memediasi secara positif tetapi tidak signifikan pada Strategi Kewirausahaan terhadap Business Performance. artinya Kreativitas menjadi faktor utama untuk inovasi, yang dapat merujuk pada sifat-sifat produk dan proses. Fokus wirausahawan mengubah ide kreatif menjadi kenyataan untuk terjadinya inovasi. Karena alasan ini, kreatif akan mencegah perusahaan untuk tetap sama dan juga membuat mereka selangkah lebih maju.

3) Inovasi Memediasi secara positif tetapi tidak signifikan pada Strategi Kewirausahaan terhadap Business Performance. Artinya Kemampuan para pemilik untuk menciptakan inovasi dalam berproduksi pada usaha kecil dan menengah memberikan dampak yang positif untuk mengembangkan usahanya. Dalam studi ini, UMKM Garmen bandung menciptakan nilai dalam industri fashion di indonesia.

\section{Daftar Pustaka}

A, R. (2011). Pengaruh Perkembangan Usaha Kecil Menengah Terhadap Pertumbuhan Ekonomi Pada Sektor Ukm Di Indonesia.

Autio, E., Kenney, M., Mustar, P., Siegel, D., \& Wright, M. (2014). Entrepreneurial innovation: The importance of context. Research Policy, 43(7), 1097-1108. https://doi.org/10.1016/j.respol.2014.01.015

Bengesi, K. M. K., \& Roux, I. Le. (2014). Strategic Entrepreneurial Response of Small and Medium Enterprises in Developing Economies. International Journal of Business and Management, 9(2), 153-165. https://doi.org/10.5539/ijbm.v9n2p153 
Donaldson, T. H., \& Donaldson, T. H. (2018). Managing the Internal Process. Credit Control in Boom and Recession, 161-173. https://doi.org/10.1057/9780230390249_12

Ferrari, A., Cachia, R., \& Punie, Y. (2009). Innovation and Creativity in Education and Training in the EU Member States: Fostering Creative Learning and Supporting Innovative Teaching Literature review on Innovation and Crea Entrepreneurship Competence View project SWAMI-Safeguards in a World of Am, (January), 1-65. Retrieved from https://www.researchgate.net/publication/265996963

Fliaster, A., \& Sperber, S. (2019). Knowledge Acquisition for Innovation: Networks of Top Managers in the European Fashion Industry. European Management Review. https://doi.org/10.1111/emre.12373

Garud, R., Gehman, J., \& Tharchen, T. (2018). Performativity as ongoing journeys: Implications for strategy, entrepreneurship, and innovation. Long Range Planning, 51(3), 500-509. https://doi.org/10.1016/j.lrp.2017.02.003

Georgellis, Y., Joyce, P., \& Woods, A. (2000). Entrepreneurial action, innovation and business performance: the small independent business. Journal of Small Business and Enterprise Development, $\quad 7(1), \quad 7-17$. https://doi.org/10.1108/EUM0000000006801

Grant, R. M. (1996). Towards a Knowledge-based Theory of Firm. Strategic Management Journal, 17, 109-122.

Hendarman, A. F., \& Tjakraatmadja, J. H. (2012). Relationship among Soft Skills, Hard Skills, and Innovativeness of Knowledge Workers in the Knowledge Economy Era. Procedia - Social and Behavioral Sciences, 52, 35-44. https://doi.org/10.1016/j.sbspro.2012.09.439

Hoglund, L., Caicedo, M. H., \& Martensson, M. (2014). Strategic Strateg ic Entrepreneurship Practices at Robotdalen - A balancing act or Not? Not ?, 1-17.

Liu, P., \& Bell, R. (2019). Exploration of the initiation and process of business model innovation of successful Chinese ICT enterprises. Journal of Entrepreneurship in Emerging Economies (Vol. 11). https://doi.org/10.1108/JEEE-09-2018-0094

Luke, B., Kearins, K., \& Verreynne, M. L. (2011). Developing a conceptual framework of strategic entrepreneurship. International Journal of Entrepreneurial Behaviour and Research, 17(3), 314-337. https://doi.org/10.1108/13552551111130736

Markowska, M., Grichnik, D., Brinckmann, J., \& Kapsa, D. (2019). Strategic orientations of nascent entrepreneurs: antecedents of prediction and risk orientation. Small Business Economics, (Sarasvathy 2001). https://doi.org/10.1007/s11187-018-0107-4

Mayasari Ginting, Y., . E., Rahman, H., \& Devianto, D. (2019). Innovation and Knowledge Management System in Creative Industry: A systematic Literature Review Using $\begin{array}{llll}\text { Metaanalysis. } \quad K n E & \text { Social } & \text { Sciences, } & \end{array}$ https://doi.org/10.18502/kss.v3i14.4340

Pratt, A. C. (2000). New media, the new economy and new spaces Article (Accepted version) (Refereed) New media, the new economy and new spaces, 31, 425-436. https://doi.org/10.1016/S0016-7185(00)00011-7

Purnomo, M., Suharyono, Suyadi, I., \& Utami, H. N. (2017). Strategic Entrepreneurship with Knowledge Management Capability Base: Study on Small Business of Garment Retail in Bandung Traditional Market West Java Province, Indonesia. International Journal of Management and Administrative Sciences (IJMAS), 4(06), 76-100.

Salunke, S., Weerawardena, J., \& McColl-Kennedy, J. R. (2019). The central role of knowledge integration capability in service innovation-based competitive strategy.

p-ISSN 2337-571X | e-ISSN 2541-562X

(C) 2020 Edunomic: Jurnal Ilmiah Pendidikan Ekonomi Fakultas Keguruan dan Ilmu Pendidikan 
Industrial Marketing Management, 76(August 2018), 144-156. https://doi.org/10.1016/j.indmarman.2018.07.004

Webb, J. W., Ketchen, D. J., \& Ireland, R. D. (2010). Strategic entrepreneurship within family-controlled firms: Opportunities and challenges. Journal of Family Business Strategy, 1(2), 67-77. https://doi.org/10.1016/j.jfbs.2010.04.002

Withers, M. C., Duane, ireland R., Miller, D., Harrison, J., \& Boss, D. (2016). Competitive landscape shifts: The influence of strategic entrepreneurship on shifts in market commonality Academy of Management Review ENTREPRENEURSHIP ON SHIFTS IN MARKET COMMONALITY Texas A \& M University Email: mwithers@m.Academy of Management Review. 